\title{
A comparative study of two groundwater treatment pilot plants
}

\author{
C. Podaru ${ }^{1}$, C. Danielescu ${ }^{1}$, D. Sonea ${ }^{1}$, A. Pacala ${ }^{2}$, I. Vlaicu ${ }^{2}$, \\ C. Cosma $^{3}$, G. Burtica ${ }^{1}$, F. Manea ${ }^{1} \&$ C. Orha ${ }^{1}$ \\ ${ }^{I}$ Politehnica University of Timisoara, Romania \\ ${ }^{2}$ AQUATIM Company, Timisoara, Romania \\ ${ }^{3}$ National Research and Development Institute for Industrial Ecology, \\ ECOIND, Bucharest, Romania
}

\begin{abstract}
This paper reports comparative results of two pilot plant technologies applied for iron and manganese removal from groundwater as part of the drinking water treatment. The first technology (FOF) consisted of a two step filtration by using Romanian natural zeolite of two granulations, and $\mathrm{ClO}_{2}$ as an oxidant and disinfecting agent. $\mathrm{ClO}_{2}$ injection was split between two columns filled with two different granulation of Romanian zeolite used as filters. The second technology (OFMU) consisted of $\mathrm{ClO}_{2}$ oxidation, one step filtration by using Romanian natural zeolite, and microfiltration-ultrafiltration. The first technology achieved good performance. The residual concentration of iron and manganese decreased below the allowed maximum concentration $\left(0.2 \mathrm{mg}^{*} \mathrm{~L}^{-1}\right.$ for iron and $0.05 \mathrm{mg} *$ $\mathrm{L}^{-1}$ for manganese). The second technology indicated a good performance only for iron removal, while the residual concentration of manganese was over the allowed maximum concentration.
\end{abstract}

Keywords: groundwater, zeolite, $\mathrm{ClO}_{2}$, microfiltration-ultrafiltration, iron, manganese.

\section{Introduction}

Groundwater has been used for household, livestock and irrigation since the earliest times [1]. The natural chemical quality of groundwater is generally good, but high concentrations of certain constituents can cause problems [2]. 
Iron and manganese cause organoleptic and operating problems when they are present in groundwater as $\mathrm{Fe}(\mathrm{II})$ and $\mathrm{Mn}(\mathrm{II})$. The processes available for their removal are either physico-chemically or biologically based [3].

Based on high cation-exchange ability as well as molecular sieve properties, natural zeolites (as cheap materials and easily available in large quantities in many parts of the world) show special importance in water and gas purification, adsorption, catalysis, agriculture and aquaculture [4].

Clinoptilolites have been found to have a high heavy metal sorption capacity, especially for manganese removal [5].

Chlorine dioxide has attracted significant commercial attention not only due to environmental concern but also due to its wide application in the field of oxidation and disinfection [6]. Chlorine dioxide $\left(\mathrm{ClO}_{2}\right)$ is one of the readily available alternatives to chlorine for disinfection and oxidation during the treatment of drinking water treatment [7].

Membrane technology (microfiltration and ultrafiltration) is well-known for the treatment of continental water for drinking water or process water production [8].

This paper aimed at evaluating the results of two pilot plants technologies used to treat aerated water from groundwater drinking treatment plant (WTP) of Timisoara city, Romania. The results are focused on iron and manganese removal, because these parameters are problematic as part of the conventional groundwater drinking treatment technology in Timisoara city. In addition, the residual concentration of chlorine dioxide was checked. The evaluation of other parameters that characterize drinking water is beyond the scope of this paper.

\section{Experimental part}

\subsection{Investigation steps}

Two pilot plants technologies described below were taken into consideration as part of this study. Water resulting from the aeration stage of the existing conventional treatment was used as the feed.

To compare the efficiency of both applied technologies total iron, total manganese and chlorine dioxide parameters were determined.

\subsection{Pilot plants equipment}

The first pilot plant (FOF) consisted of two steps of filtration on various zeolite granulation $(1 \div 5 \mathrm{~mm}$ for filter 1 , and $0.4 \div 1.6 \mathrm{~mm}$ for filter 2$)$, separated by the oxidation step with chlorine dioxide. The flow rate for filter 1 was $\mathrm{D}_{1}=80 \mathrm{~L} / \mathrm{h}$, and $\mathrm{D}_{2}=60 \mathrm{~L} / \mathrm{h}$ for filter 2 . The technological scheme of this pilot plant is presented in the figure 1.

The second pilot plant (OFMU) consisted of the first step of oxidation with chlorine dioxide, the second step of filtration on zeolite of $1 \div 5 \mathrm{~mm}$ granulation, followed by microfiltration-ultrafiltration module. The microfiltration was a 
spiralled filter cartridge, model CA-0804-04 OF 50 microns, followed by an ultrafiltration membrane made of hollow fibres, with tangential ultrafiltration TRIHIGH, model CLN4000No (50-70 KDalton). The module was manufactured by PIASA Engineering \& Trading S.A., U.S.A. The flow rate on zeolite was 100 $\mathrm{L} / \mathrm{h}$. The flow rate for microfiltration-ultrafiltration module was $200 \mathrm{~L} / \mathrm{h}$. The technological scheme of pilot plant is presented in the figure 2 .

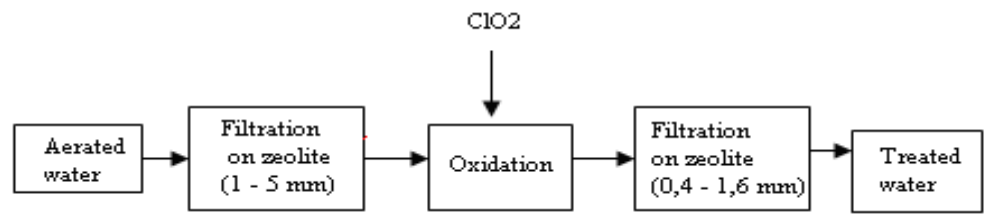

Figure 1: Technological scheme of FOF pilot plant.

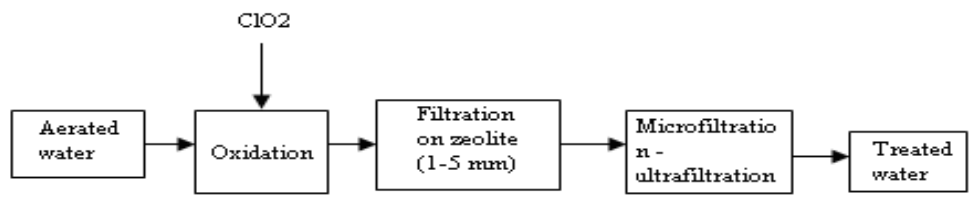

Figure 2: $\quad$ Technological scheme of OFMU pilot plant.

For both applied technologies, the inside diameter of columns equipped with zeolite was $\mathrm{d}=125 \mathrm{~mm}$, and the height was $\mathrm{H}=1 \mathrm{~m}$.

To equip the column filter, the studied zeolite came from Mirsid (Romania), with clinoptilolite (68\% wt.) as major component and the following composition (\% w/w): 62.20\% $\mathrm{SiO}_{2} ; 11.65 \% \mathrm{Al}_{2} \mathrm{O}_{3} ; 1.30 \% \mathrm{Fe}_{2} \mathrm{O}_{3} ; 3.74 \% \mathrm{CaO} ; 0.67 \% \mathrm{MgO}$; $0.72 \% \mathrm{Na}_{2} \mathrm{O} ; 3.30 \% \mathrm{~K}_{2} \mathrm{O} ; 0.28 \% \mathrm{TiO}_{2}$ [9].

The concentration of total manganese, total iron and chlorine dioxide was determined. The quantitative determination of manganese was based on the Romanian standardized methods, i.e., SR ISO 3264-87 for manganese [10] and SR ISO 13315-96 for iron [11]. $\mathrm{ClO}_{2}$ determination was made based on American Standard Method as DPD Method [12]. $\mathrm{ClO}_{2}$ was prepared in-situ by using Oxiperm C164 Fully-Automatic Chlorine Dioxide Generation System, manufactured by Alldos Eichler $\mathrm{GmbH}$, Germany, by using $\mathrm{HCl}$ and $\mathrm{NaClO}_{2}$ solutions as reagents. The applied $\mathrm{ClO}_{2}$ dose was calculated taking in account the reaction stoichiometry for the oxidation process of manganese and iron ions (equations 1, 2 and 3).

$$
\mathrm{Mn}^{2+}+2 \mathrm{ClO}_{2}+2 \mathrm{H}_{2} \mathrm{O} \rightarrow \mathrm{MnO}_{2(\mathrm{~S})}+2 \mathrm{ClO}_{2}+4 \mathrm{H}
$$

Based on stoichiometry, $2.45 \mathrm{mg}$ of chlorine dioxide are required to oxidise 1 $\mathrm{mg}$ of soluble manganese and $1.2 \mathrm{mg}$ of chlorine dioxide are required to oxidise $1 \mathrm{mg}$ of soluble iron.

$$
\mathrm{Fe}^{2+}+\mathrm{ClO}_{2}+10 \mathrm{H}_{2} \mathrm{O} \rightarrow 4 \mathrm{Fe}(\mathrm{OH})_{3(\mathrm{~S})}+\mathrm{Cl}^{-}+8 \mathrm{H}
$$

Three different doses of $\mathrm{ClO}_{2}$ corresponded to three different ratios (R). 


$$
\mathrm{D}_{\mathrm{ClO}_{2}}=\mathrm{x} \cdot \mathrm{R}, \mathrm{x}=\mathrm{C}_{\mathrm{Fe}}{ }_{d i z} \cdot 1.2+\mathrm{C}_{\mathrm{Mn}}{ }_{d i z} \cdot 2.5, \mathrm{R}=1.5 ; 1 ; 0 .
$$

The total removal efficiency for all parameters monitored was calculated by using equation 4 :

$$
E=\left(C_{\text {initial }}-C_{\text {final }}\right) \cdot 100 / C_{\text {initial }}
$$

where $\mathrm{C}_{\text {initial }}$ and $\mathrm{C}_{\text {final }}$ represent initial and final concentrations of each parameter before and after technology application.

The maximum allowed contaminant level for drinking water is as follow: 0.2 $\mathrm{mg} / \mathrm{L}$ for iron, $0.05 \mathrm{mg} / \mathrm{L}$ for manganese [13] and $0.8 \mathrm{mg} / \mathrm{L}$ for chlorine dioxide [14].

\section{Results and discussion}

\subsection{Pilot plant influent quality}

Table 1 shows the feed water quality with respect to total manganese and total iron concentrations before the application of both pilot plant technologies.

Table 1: $\quad$ Feed water quality.

\begin{tabular}{|l|l|c|c|c|c|c|c|c|}
\hline \multirow{2}{*}{} & \multicolumn{7}{|c|}{ Applied technology } \\
\cline { 2 - 9 } & \multicolumn{9}{|c|}{ FOF } \\
$\begin{array}{l}\text { Para- } \\
\text { meter }\end{array}$ & average & $\min$ & $\max$ & $\begin{array}{c}\text { no. of } \\
\text { measur. }\end{array}$ & average & min & max & $\begin{array}{c}\text { no. of } \\
\text { measur. }\end{array}$ \\
\hline $\begin{array}{l}\text { Total } \\
\text { Mn, } \\
\mathrm{mg} / \mathrm{L}\end{array}$ & 0.67 & 0.61 & 0.78 & 10 & 0.96 & 0.23 & 2.90 & 7 \\
\hline $\begin{array}{l}\text { Total } \\
\text { Fe, } \\
\mathrm{mg} / \mathrm{L}\end{array}$ & 2.29 & 0.61 & 3.06 & 10 & 2.88 & 1.82 & 4.84 & 7 \\
\hline
\end{tabular}

\subsection{Total manganese removal}

Table 2 shows the values of residual total manganese concentration after the application of both pilot plants. The results revealed that by using FOF technology, at $\mathrm{ClO}_{2}$ dose corresponding to $\mathrm{R}=1$, the value of manganese residual concentration varied between 0.01 and $0.05 \mathrm{mg} / \mathrm{L}$, which is below maximum allowed concentration, while by using OFMU at $\mathrm{ClO}_{2}$ dose corresponding to $\mathrm{R}=0.8$, the values varied between 0.03 and $1.10 \mathrm{mg} / \mathrm{L}$, exceeding the maximum allowed concentration in most cases.

Figure 3 shows the global efficiency of total manganese removal for both applied technologies. The removal efficiency of FOF technology at $\mathrm{ClO}_{2}$ dose corresponding to $\mathrm{R}=1$ varied from 92.06 to $98.61 \%$, and from 62.10 to $86.96 \%$ for OFMU technology at $\mathrm{ClO}_{2}$ dose corresponding to $\mathrm{R}=0.8$. The total manganese removal efficiency for the first applied technology was better than for the second one, which involved the microfiltration-ultrafiltration module. 
Table 2: Total manganese concentrations for the effluents of the pilot plants.

\begin{tabular}{|c|c|c|c|c|}
\hline \multirow{2}{*}{ Applied technology } & \multicolumn{4}{|c|}{ Total Mn concentration [mg/L] } \\
\cline { 2 - 5 } & average & $\min$ & $\max$ & $\begin{array}{c}\text { number of } \\
\text { measurements }\end{array}$ \\
\hline FOF $; \mathrm{R}=1$ & 0.03 & 0.01 & 0.05 & 10 \\
\hline OFMU $; \mathrm{R}=0.8$ & 0.28 & 0.03 & 1.10 & 7 \\
\hline
\end{tabular}

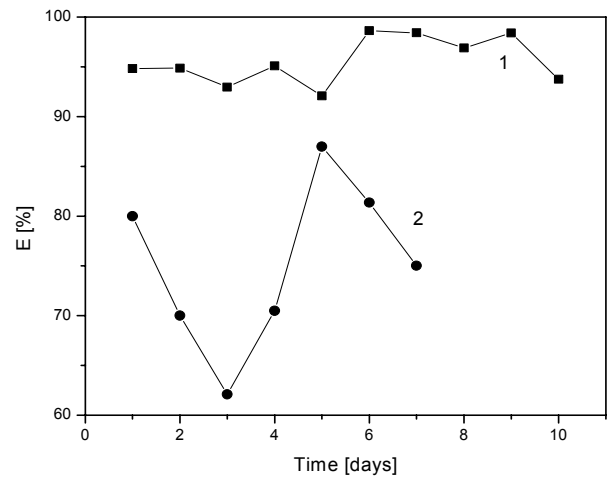

Figure 3: The evolution of total manganese removal efficiency for both applied pilot plant technologies; 1- FOF $(\mathrm{R}=1)$, 2- OFMU $(\mathrm{R}=0.8)$.

Table 3: Total manganese concentration for the effluents of the pilot plants; other ratios of $\mathrm{ClO}_{2}$ dose.

\begin{tabular}{|c|c|c|c|}
\hline $\begin{array}{c}\text { Type of } \\
\text { technology }\end{array}$ & $\mathrm{R}$ & $\begin{array}{c}\text { Residual total Mn } \\
\text { concentration }[\mathrm{mg} / \mathrm{L}]\end{array}$ & $\begin{array}{c}\text { Removal efficiency } \\
{[\%]}\end{array}$ \\
\hline \multirow{2}{*}{ FOF } & 0.8 & $0.06 \div 0.19$ & $36.37 \div 85.00$ \\
\cline { 2 - 4 } & 1.5 & $0.01 \div 0.05$ & $93.59 \div 98.46$ \\
\hline \multirow{2}{*}{ OFMU } & 1 & 0.11 & 77.55 \\
\cline { 2 - 4 } & 1.5 & 0.01 & $93.00 \div 96.43$ \\
\hline
\end{tabular}

Studies were carried out for other ratio of $\mathrm{ClO}_{2}$ dose. For both technologies, the high $\mathrm{ClO}_{2}$ dose led to very good results related to the manganese removal, but the residual $\mathrm{ClO}_{2}$ concentration in the effluent was an additional problem. This aspect will be discussed in the next section.

\subsection{Total iron removal}

For both of the applied technologies the total iron residual concentration was below the maximum allowable concentration. The results shown in table 4 , give 
values of total iron concentration in pilot plants effluent. The results reveal that by using FOF technology and $\mathrm{ClO}_{2}$ dose corresponding to $\mathrm{R}=1$, the value of manganese residual concentration varied from 0.01 to $0.02 \mathrm{mg} / \mathrm{L}$, while by using OFMU technology and $\mathrm{ClO}_{2}$ dose corresponding at $\mathrm{R}=0.8$, the values varied from 0.00 to $0.04 \mathrm{mg} / \mathrm{L}$.

Table 4: $\quad$ Total iron concentrations for the effluents of the pilot plants.

\begin{tabular}{|c|c|c|c|c|}
\hline \multirow{2}{*}{ Applied technology } & \multicolumn{4}{|c|}{ Total Fe concentration [mg/L] } \\
\cline { 2 - 5 } & average & $\min$ & $\max$ & $\begin{array}{c}\text { number of } \\
\text { measurements }\end{array}$ \\
\hline FOF; $\mathrm{R}=1$ & 0.01 & 0.01 & 0.02 & 10 \\
\hline OFMU; $\mathrm{R}=0.8$ & 0.02 & 0.00 & 0.04 & 7 \\
\hline
\end{tabular}

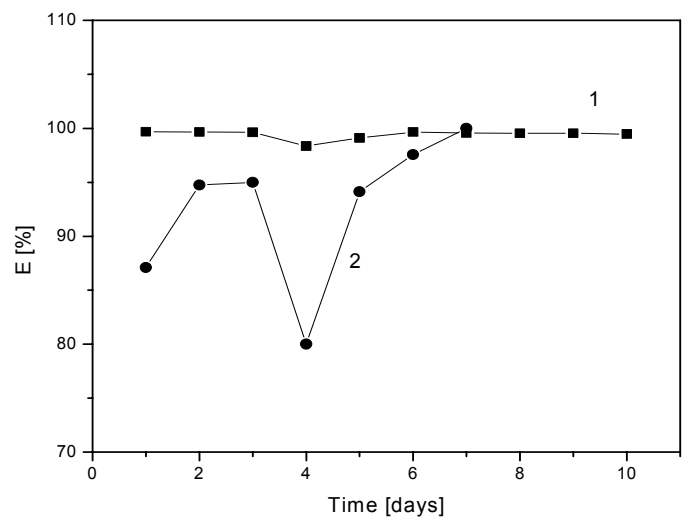

Figure 4: The variation of total iron removal efficiency for both applied technologies; 1- FOF ( $\mathrm{R}=1)$, 2- OFMU $(\mathrm{R}=0.8)$.

Figure 4 shows the results of total iron removal efficiency. The values obtained are $99.10 \div 99.67 \%$ for the FOF technology for $\mathrm{ClO}_{2}$ dose corresponding to $\mathrm{R}=1$, and $80.00 \div 100.00 \%$ for OFMU technology, for $\mathrm{ClO}_{2}$ dose corresponding to $\mathrm{R}=0.8$.

Table 5 shows the values obtained for total iron for other ratios of $\mathrm{ClO}_{2}$ dose. For all situations, residual total iron concentration was below the maximum allowed concentration.

\subsection{Total reduction degree by chlorine dioxide}

Table 6 shows the values of residual $\mathrm{ClO}_{2}$ concentration for both applied technology. In both cases, the value did not exceed the maximum allowed concentration. The interval of residual concentration of $\mathrm{ClO}_{2}$ varied from 0.11 to $0.18 \mathrm{mg} / \mathrm{L}$ for $\mathrm{FOF}$ technology, for $\mathrm{ClO}_{2}$ dose corresponding at $\mathrm{R}=1$, and from 0.06 to $0.20 \mathrm{mg} / \mathrm{L}$ for OFMU technology, for $\mathrm{ClO}_{2}$ dose corresponding to $\mathrm{R}=0.8$. 
Table 5: Total iron concentrations for the effluents of the pilot plants; other ratios of $\mathrm{ClO}_{2}$ dose.

\begin{tabular}{|c|c|c|c|}
\hline $\begin{array}{c}\text { Type of } \\
\text { technology }\end{array}$ & $\mathrm{R}$ & $\begin{array}{c}\text { Residual total Fe } \\
\text { concentration }[\mathrm{mg} / \mathrm{L}]\end{array}$ & $\begin{array}{c}\text { Removal efficiency } \\
{[\%]}\end{array}$ \\
\hline \multirow{2}{*}{ FOF } & 0.8 & 0.01 & $0 \div 14.29$ \\
\cline { 2 - 4 } & 1.5 & $0.01 \div 0.02$ & $90 \div 97.59$ \\
\hline \multirow{2}{*}{ OFMU } & 1 & 0.01 & $93.00 \div 96.43$ \\
\cline { 2 - 4 } & 1.5 & 0.01 & $95.24 \div 97.22$ \\
\hline
\end{tabular}

Table 6: Chlorine dioxide concentrations for the effluents of both pilot plants.

\begin{tabular}{|c|c|c|c|c|}
\hline \multirow{2}{*}{ Applied technology } & \multicolumn{4}{|c|}{$\mathrm{ClO}_{2}$ concentration [mg/L] } \\
\cline { 2 - 5 } & average & $\min$ & $\max$ & $\begin{array}{c}\text { number of } \\
\text { measurements }\end{array}$ \\
\hline FOF; $\mathrm{R}=1$ & 0.14 & 0.11 & 0.18 & 10 \\
\hline OFMU; $\mathrm{R}=0.8$ & 0.11 & 0.06 & 0.20 & 7 \\
\hline
\end{tabular}

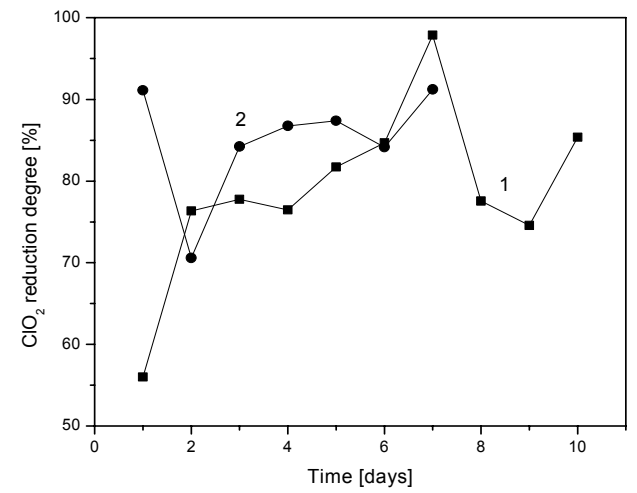

Figure 5: The variation of chlorine dioxide reduction degree, for both applied technologies; 1- FOF $(\mathrm{R}=1)$, 2- OFMU $(\mathrm{R}=0.8)$.

The values of total reduction degree by $\mathrm{ClO}_{2}$ for both applied technology are presented in figure 5, which shows $74.55 \div 97.86 \%$ for FOF technology, for $\mathrm{ClO}_{2}$ dose corresponding at $\mathrm{R}=1$, and $84.15 \div 91.21 \%$ for OFMU technology, for $\mathrm{ClO}_{2}$ dose corresponding to $\mathrm{R}=0.8$.

The results obtained for other ratios of chlorine dioxide are shown in table 7 . For all situations, the residual chlorine dioxide concentration was below the maximum allowed concentration. 
Table 7: Residual chlorine dioxide concentrations for the effluents of the pilot plants; other ratios of $\mathrm{ClO}_{2}$ dose.

\begin{tabular}{|c|c|c|c|}
\hline $\begin{array}{c}\text { Type of } \\
\text { technology }\end{array}$ & $\mathrm{R}$ & $\begin{array}{c}\text { Residual chlorine dioxide } \\
\text { concentration }[\mathrm{mg} / \mathrm{L}]\end{array}$ & $\begin{array}{c}\text { Reduction degree } \\
{[\%]}\end{array}$ \\
\hline \multirow{2}{*}{ FOF } & 0.8 & $0.09 \div 0.14$ & $64.86 \div 83.91$ \\
\cline { 2 - 4 } & 1.5 & $0.11 \div 0.20$ & $65.22 \div 81.82$ \\
\hline \multirow{2}{*}{ OFMU } & 1 & $0.09 \div 0.12$ & $0 \div 47.83$ \\
\cline { 2 - 4 } & 1.5 & $0.03 \div 0.13$ & $79.69 \div 98.77$ \\
\hline
\end{tabular}

\section{Conclusions}

For both applied technologies, the oxidation process was carried out by using $\mathrm{ClO}_{2}$ at different doses for iron and manganese oxidation. In the case of FOF application, the optimum ratio related to $\mathrm{ClO}_{2}$ dose was $\mathrm{R}=1$, corresponding to a residual concentration of total iron below maximum allowed concentration, and the removal efficiency of $99.10 \div 99.67 \%$. The residual concentration of manganese removal was situated below the maximum allowed concentration, and the removal efficiency was $92.06 \div 98.61 \%$. Chlorine dioxide residual concentration was below maximum allowed concentration.

The results obtained by the OMFU technology showed the iron residual concentration below maximum allowed concentration at $\mathrm{R}=0.8$, with removal efficiencies of $80.00 \div 100 \%$, but the residual concentration of total manganese was higher than the maximum allowed concentration, with removal efficiencies from 62.10 to $86.96 \%$.

By comparing both applied technologies, the main finding is that FOF technology gave better results with respect to the iron and manganese ions removal.

\section{Acknowledgement}

This work was supported by project CEEX-PROAQUA No. 631/03.10.2005.

\section{References}

[1] Water quality assessments, A guide to the use of biota, sediments and water in environmental monitoring, Edited by Deborah Chapman, pp. 372, 1992.

[2] Water quality assessments, A guide to the use of biota, sediments and water in environmental monitoring, Edited by Deborah Chapman, pp. 390, 1992.

[3] Pacini, V.A., Ingallinella, A.M., Sanguinetti, G., Removal of iron and manganese using biological roughing up flow filtration technology, Water Research 39 (2005), pp. 4463-4475

[4] Sprynsky, M., Lebedynets, M., Terzyk, A.P., Kowalczyk, P., Namieśnik J. \& Buszewski, B., Ammonium sorption from aqueous solutions by the 
natural zeolite Transcarpathian clinoptilolite studied under dynamic conditions, Journal of Colloid and Interface Science, Vol 284, pp. 408-415, 2005.

[5] Doula, M.K., Removal of $\mathrm{Mn}^{2+}$ ions from drinking water by using clinoptilolite and a clinoptilolite-Fe oxide system, Water research, pp. 40 3167-3176, 2006.

[6] Deshwal, B.R., Jin, D.S., Lee, S.H., Moonb, S.H., Jung, J.H., Lee, H.K., Removal of NO from flue gas by aqueous chlorine-dioxide scrubbing solution in a lab-scale bubbling reactor, Journal of Hazardous Materials 150, pp. 649-655, 2008.

[7] Shin, H.S., Jung, D.G., Determination of chlorine dioxide in water by gas chromatography-mass spectrometry, Journal of Chromatography A, 1123, pp.92-97, 2006.

[8] Bonnelye, V., Guey, L., J. Del Castillo, UF/MF as pre-treatment: the real benefit, Desalinisation 222, pp. 59-65, 2008.

[9] Orha, C., Burtica, G., Manea, F., Pop, A., The retaining capacity of the zeolite used in water disinfection, Bulletin of the Transilvania University of Brasov, ISSN 1223-9631, pp. 138-142, 2006.

[10] Drinking Water Standard for manganese determination, SR ISO 3264-87

[11] Drinking Water Standard for iron determination, SR ISO 13315-96

[12] Standard Methods for the Examination of Water and Wastewater, $19^{\text {th }}$ Edition, Ed. By Andrew D. Eaton Lenore S. Clesceri, Arnold E. Greenberg, 1995.

[13] Romanian Potable Water Low No.428/2002 and 311/2004

[14] United States Environmental Protection Agency (USEPA), National Primary Drinking Water Regulations: Disinfectants and Disinfection Byproducts, www.epa.gov/OGWDW/mdbp/dbpfr.html 